\title{
Some Aspects of Monastic Diets from Thebes
}

\section{A Comparative Study of the Consumption of Fish and Meat}

\author{
Hind Salah El-Din Somida Awad \\ Lecturer, Faculty of Archaeology, Egyptology Department, Cairo University, \\ Cairo, Egypt \\ aveagia417138@gmail.com
}

\begin{abstract}
Egypt was the homeland of monasticism from at least the fourth century AD. The aim of this article is to investigate the consumption of fish and meat in the monastic diets of Thebes from the sixth to the eighth centuries $\mathrm{AD}$, and other monastic sites of Middle Egypt, as well as in Palestine, where recent studies have illustrated monastic diets. This in turn could shed additional light on the case of Thebes.
\end{abstract}

\section{Keywords}

Monastic - Diet - Thebes - Bawit - kom El-Nana - Meat - Fish - Adam - Christ

Food played an essential role in monastic life, for it was connected to the flesh and its temptations. This was why ascetics avoided eating body-warming foodstuffs from the very beginnings of Christian monasticism, although such fare was not forbidden in the Old and New Testaments. Hence Christian monastic literature from Egypt in many instances asserted that animal products were not common items in monastic daily diets. However, archaeological and textual evidence has appeared that challenges this idea, thus making rethinking monastic diets and their role in the spiritual life of the monks obligatory.

In fact, Thebes perhaps gives the best insight as it was characterized by every variety of monastic types flourishing side by side, as well as producing an abundance of archaeological and textual sources especially from the sixth to 
the eighth centuries. ${ }^{1}$ Indeed the work of Winlock and Crum on the Monastery of Epiphanius revealed many aspects of the Theban diets in late antiquity. Winlock has pointed to the grains, fruits and other botanical specimens found in Cell A in the soma of the Monastery of Cyriacus, and in the rubbish hole in Room 5; he also deduced "that in the 7 th century the crops were very much what they are today". As well he proposed that the seed-pods of the sunt-tree that had been collected in Cell A were "either for making a blue dye or for tanning leather", finally adding that the "berries of the Juniperus phoenicea were common enough to be used in large quantities as an embalming agent in the graves". ${ }^{2}$ From the other side Crum supplemented the list of Winlock from documents found in the site and elsewhere in his study for the literary material of the monastery, where he noticed that "of many of the letters exchanged between the members of a poor community of hermits the inevitable subject must be food". ${ }^{3}$

Moreover, Täckholm identified 33 species from the plant material of the monastery of Phoebammon, which consisted mainly of forage and various food plants of the monastery. He mentioned that these findings do hold a great importance for the history of the new introductions of plants in the GraecoRoman times established themselves during the early Coptic period. ${ }^{4}$

Without doubt these works are essential for the history of monastic diets at Thebes, but they deal only with the plant material. When Crum mentioned fish he just noted that from the Life of Pesenthius, it "was unusual in the diet of hermits, but was allowed to those in ill-health, and it was eaten by Shenoute's monks, though perhaps here too in illness only", adding too that in the texts from the monastery "it is but seldom named". The same applies to his mention of meat where it "must be referred to, if only to record its absence from all these monastic documents", 5 even when he mentioned "a deed of gift from Jeme presenting the monastery of Phoebammon with a donation of $3^{1}$ sheep and 14 goats, as well some letters in the Pesenthian dossier relating to cattle belonging to a monastery", he concluded "either that in those days was the fare of coenobites and not of the hermits, or else that the monasteries owned flocks

1 H. E. Winlock and W. E. Crum, The Monastery of Epiphanius at Thebes, part I, New York, 1926, p. 125 .

2 H. E. Winlock and W. E. Crum, The Monastery of Epiphanius at Thebes, p. 61.

3 H. E. Winlock and W. E. Crum, The Monastery of Epiphanius at Thebes, p. 144.

4 V.Täckholm, "Botanical Identifications of the Plants Found at the Monastery of Phoebammon," in: Le Monastère de Phoebammon dans la Thébaïde, ed. C. Bachatly, Cairo, 1961, pp. 3-38.

5 H. E. Winlock and W. E. Crum, The Monastery of Epiphanius at Thebes, p. 148-149. 
without using them for food". ${ }^{6}$ Also, though Täckholm's study could be added to the repertoire of the plant list given by Winlock and Crum, unfortunately his study did not consider fish and meat at all. ${ }^{7}$ On the other hand, none of these scholars tried to interpret even the plant material through its spiritual contexts and did not examine implications of the diet within the monastic lives in specific monasteries, an approach that could lead scholars to search in the spiritual role of food items even if only through plant materials, i.e. to explain why monks consumed some specific plant materials and did not prefer to include others or animal products or fish too in their diets.

Therefore, reexamining food items from the main Theban monastic sites; the semi-anchoritic Monastery of Epiphanius, ${ }^{8}$ the coenobitic monastery of Phoebammon II, ${ }^{9}$ the new finds of the region of тT 85, 87, 95 in Qurna i.e. the residence of the Chalcedonian semi-anchorite Father Ananias, bishop of Armant, ${ }^{10}$ as well тT 29 , the residence of the famous monk 'Frange', from which more than goo ostraca have been discovered so far, ${ }^{11}$ could reveal more facts about the monastic diets of Thebes.

Many archaeological and textual sources have demonstrated that the Theban monks depended primarily on wheat, bread, lentil, and oil. However, Winlock found in the archaeological evidence of the Monastery of Epiphanius fish nets of linen twine from 5 to $40 \mathrm{~mm}$ wide with meshes, as well in the rubbish under the floor of the first tower, together with a broken net with large mesh

6 W. E. Crum and G. Steindorff, Koptische Rechtsurkunden des Achten Jahrhunderts aus Djeme (Theben), part I, Leipzig, 1912, nr.112; H. E. Winlock and W. E. Crum, The Monastery of Epiphanius at Thebes, p. 149 .

7 V. Täckholm, "Botanical Identifications of the Plants Found at the Monastery of Phoebammon," p. 3

8 H. E. Winlock and W. E. Crum, The Monastery of Epiphanius at Thebes; W.E. Crum and H.G. Evelyn White, The Monastery of Epiphanius at Thebes, part II, New York, 1926; T.G. Wilfong, Women of Djeme: Lives in a Coptic Town in Late Antique Egypt, Ann Arbor-Michigan, 2002, pp. 6-7,17-18; and L.P. Malcolm, "Dayr Epiphanius," in: The Coptic Encyclopedia, ed. A.S. Atiya, vol. 3, New York, 1991, pp. 8oo-8o2.

9 W.E. Crum, Coptic Ostraca from the Collection of the Egypt Exploration Fund, the Cairo Museum and Others, London, 19o2; and W. Godlewski, "Dayr Apa Phoibammon- Buildings," in: The Coptic Encyclopedia 3, pp. 780-781.

10 H. Salah El-Din, A Group of Coptic Ostraca from Thebes, Publication and Analytical study, [unpublished PhD thesis], Cairo, 2013; H. Salah El-Din, "Three Coptic Ostraca from TT85 in Qurna-Western Thebes," Heritage:Journal of Multidisciplinary Studies in Archaeology, 4 (2016), pp. 173-182; and H. Behlmer, "Christian Use of Pharaonic Sacred Space in Western Thebes," in: Sacred Space and Sacred Function in Ancient Thebes, ed. P.F. Dorman and B.M. Bryan, Chicago, 2007, pp. 164-168.

11 H. Behlmer, "Christian Use of Pharaonic Sacred Space," p. 163; A.Boud'hors and C. Heurtel, Les Ostraca Coptes de TT29 autour du moine Frange, vol.1, Brussels, 2010 ; and A. Boud'hors and C. Heurtel, Les Ostraca Coptes de TT29 autour du moine Frange, vol. 2, Brussels, 2010. 
and a $5 \mathrm{~mm}$. cord edging, a quantity of linen twine suitable for net making and repairing, which definitely supposes that the monks supplied their own fish and thus did not need to request it from others. This explains why the fish supply is not mentioned in the textual sources. ${ }^{12}$ In addition, there appeared in the textual sources of тT 29 references to fish that denote its consumption, whether fresh or salted. ${ }^{13}$

With regard to meat at Thebes, it is remarkable that although some traces of unspecified dung were found in Tт $85,{ }^{14}$ and there is a mention of a fodder in a Coptic ostracon from TT29, ${ }^{15}$ the monks of Thebes abstained completely from eating meat, as there is no mention of its consumption at all - as far as I know - even in the considerable number of Coptic textual monastic sources of Thebes. ${ }^{16}$ Thus the supposition must be that the dung traces of тт 85 and the fodder mentioned at the тт29 were intended for some beasts of burden frequently used by monks for transport, and that meat must have been available, at least in theory.

On the other hand, the literary sources of the monastery of Phoebammon ${ }^{17}$ and the regions of тт $85,87,95$ have shown no consumption of fish and meat so far, ${ }^{18}$ although these later sources are still undergoing research and excavation that could reveal more about monastic diets in which fish and meat may be mentioned. We can note that the case of the Monastery of Phoebammon is strange because this monastery has produced a large surviving corpus of textual sources in which no mention so far is made for consumption of fish or meat at all.

Outside Thebes, fish was found in some regions of Middle Egypt; the coenobitic monastery of Apa Apollo at Bawit, ${ }^{19}$ where short texts relating to the food supply of that monastery bear evidence of the daily deliveries of grain, wine,

12 Winlock and Crum, The Monastery of Epiphanius at Thebes, p. 71: Wilfong, Women of Djeme, p. 17 .

13 A. Boud'hors, C. Heurtel, Les Ostraca Coptes de tr29 autour du moine Frange, Vol.1, nrs.96, 257, 262, 348,773: A. Boud'hors, C. Heurtel, Les Ostraca Coptes de TT29 autour du moine Frange, Vol. 2,p. 59 .

14 Behlmer, "Christian Use of Pharaonic Sacred Space," p. 164.

15 Boud'hors and Heurtel, Les Ostraca Coptes de TT 29, vol. 1, nr.643; Boud'hors and Heurtel, Les Ostraca Coptes de TT 29, vol. 2, p. 59.

16 Winlock and Crum, The Monastery of Epiphanius at Thebes, p. 149.

17 W.E. Crum, Coptic Ostraca from the Collection of the Egypt Exploration Fund, the Cairo Museum and Others.

18 H. Salah El-Din, A Group of Coptic Ostraca from Thebes, Publication and Analytical study, [unpublished PhD thesis], Cairo, 2013; H. Salah El-Din, "Three Coptic Ostraca from TT85 in Qurna-Western Thebes."

19 S.J. Clackson, Coptic Documents Relating to the Monasteries of Apa Apollo at Bawit and Titkooh in the Hermopolite Nome (PhD diss. University of London, 1996), p. 269. 
and fish, mainly pickled and salted. Also the archaeological record confirms the regular consumption of fish products in this location. ${ }^{20}$ As well, the monastic site of Kom el-Nana situated $304 \mathrm{~km}$ south of Cairo on the east bank of the Nile at the southern edge of Tell el-Amarna that has been dated to $425 / 5 \mathrm{O}^{-}$ 650 via coinage and pottery, has obviously provided much evidence of fish bones and shellfish. ${ }^{21}$

With regard to meat, in the coenobitic Monastery of Apa Thomas at Wadi Sarga in Middle Egypt ${ }^{22}$ there is found in a Coptic letter a mention of meat: "Give it to APA Mena, from APA Papnoute, the steward. Be so kind when Papa John comes to you, give (him) a can [of] oil and a little meat, farewell in the Lord," ${ }^{23}$ which could imply that APA Mena had meat. It is also worth noting that the monks of this monastery consumed salted fish as well. ${ }^{24}$ Furthermore, there was mention of a piggery in a letter from Apa Enoch to his brother Cosma that indeed denotes a monastic husbandry for pigs: "APA Enoch it is writes to my brother Cosma, (saying,) set 4 sucking-pigs apart, in a place by themselves, and give them a little barley, that their bodies may improve somewhat thereby. For it is desired to give them to the Pagarch's bride. By all means, therefore, do not leave the matter undone". ${ }^{25}$ Also, mention of a piggery was found in the coenobitic monastery of Apa Apollo at Bawit, in an order to waive polltax liability, where the brothers of the poll-tax are ordered not to hold Phoebammon of the piggery liable for the tax, until the person issuing this order has had a word with them: "Our father is the one who writes to his sons, the brothers of the poll-tax. Do not hold Phoibamon of the piggery liable for poll-tax until I speak with you". ${ }^{26}$ Furthermore, in the monastic site of Kom el-Nana, mammal bones were found from alley and floor deposits, as opposed to the middens that contained most of the bird and fish bone, which demonstrates

$20 \quad$ T.S. Richter, "Daily life, Documentary Evidence," in: Coptic Civilization. Two Years of Christianity in Egypt, ed. G. Gabra, New York, 2014, p. 138.

21 R.M. Luff, "Monastic Diet in Late Antique Egypt: Zooarchaeological Finds from Kom elNana and Tell el- Amarna, Middle Egypt," Environmental Archaeology, 12 (2) (2007), pp. 161-174.

22 J. Cromwell, "A Coptic Epistolary Exercise from Wadi Sarga," Journal of Egyptian Archaeology, 99 (2013), pp. 272-275; W.E. Crum and H.I. Bell, Wadi Sarga: Coptic and Greek Texts from Excavations Undertaken by the Byzantine Research Account, Copenhagen, 1922, pp. 1-13, 26, and 89 .

23 Crum and Bell, Wadi Sarga, pp. 145-146, nr. 181.

24 Crum and Bell, Wadi Sarga, pp. 26, nr. 92.

25 Crum and Bell, Wadi Sarga, pp. 98-99, nr. 107; and E. Wipszycka, "Resources and Economic Activities of the Egyptian Monks", Journal of Juristic Papyrology, 41 (2011), p. 213.

26 Wipszycka, "Resources and Economic Activities," p. 213; Clackson, Coptic Documents Relating to the Monasteries of Apa Apollo at Bawit, pp. 264 and 296, nr. 67. 
clearly that the monastic community had consumed beef, pork, and ovicaprid flesh. It is also evident that the community ate chicken, pigeons, doves, the occasional duck, quail, and shellfish. ${ }^{27}$

It is worth adding here, though the evidence is not from Middle Egypt, that some literary sources demonstrated the presence of meat from the monastic site at Tell Edfu, approximately $113 \mathrm{~km}$ south of Luxor, where it is mentioned in a letter on a Coptic ostracon from the insignificant 'Jacob' to the deacon 'Akylas'. The writer states at the end of the letter that they - referring to him and his brothers - will receive the small quantity of meat. ${ }^{28}$

Furthermore, beyond Egypt some instances of meat and fish were found in Palestine where animals may have been kept for human consumption, because remains of animal pens were found outside the Monasteries of Deir ash-Sha'ir and Umm 'Uweini in the Hauran. This suggests a breeding for domesticated animals. Animal bones have been found; over 40,0oo animal bones have been recovered at Deir 'Ain 'Abata, which were mainly of horse, cattle, pig, sheep/ goat, fallow deer, roe deer, domestic fowl, partridge, quail, and various fish species which indicate a versatile exploitation of local and imported animals. Bones mainly belonging to cattle, pig, sheep, goat, domestic fowl, and fish were found also at Laura of Dayr al-Qattar al-Byzanti. At Mount Nebo, bones from the sixth to the eighth centuries AD were found in the refuse heap of the monastery and are supposed to have originated from the kitchen. In Jabal Harûn, the finds of one room of the monastery that may have served as a pilgrims' hostel comprise 4,682 bones, of which $51 \%$ are fish bones, $43 \%$ are mammal bones, and the remaining $6 \%$ are from birds. Judging from the associated pottery, the finds could be dated to the late fifth century and the sixth century, although these remains may not represent the monks' diet. However, fish bones in particular have been found in the other parts of the monastery. The fish bone finds especially suggest that fish may have had a wider importance in the diet of the monks than previously thought. ${ }^{29}$ In all these cases it is probable that the monks consumed fish and meat or even various items of body-warming foodstuffs.

Therefore, although monastic communities shared some food items, they were not all similar in their dietary habits. That could be primarily due to the fact that the rules and details of monasticism itself and in turn its dietary laws

27 R.M. Luff, "Monastic diet in Late Antique Egypt: Zooarchaeological finds from Kom elNana and Tell el-Amarna, Middle Egypt", Environmental Archaeology, 12 (2) (2007).

28 S. Bacot, Ostraca Grecs et Coptes de TELL Edfou:Des fouilles Franco-Polonaises sur le site de Tell Edfou,Bibliothèque d'Etudes Coptes, vol. 19, Cairo, 20o9, p. 54, nr. 29.

29 N. Heiska, The Economy and Livelihoods of the Early Christian Monasteries in Palestine (MA diss., Helsinki, 2003), pp. 46-47. 
were not explained in the Bible. This recalls the old monastic life of the fourth century. For example, in the monastery founded by Shenoute in Egypt, whose leaders did not exert any effort to influence other monasteries, ${ }^{30}$ the dietary habits as observed in Shenoute's monastic congregation were different according to different categories of food recipients. The daily ration of healthy monks was close to the modest diet of wage-earners outside the monastery, and was even diminished on the two fast days a week. The convalescent diet served to the sick and weak in the infirmary of the monastery, however, was much more diversified and included kinds of foodstuff strictly forbidden to healthy monks, such as fish, dairy products, and poultry. ${ }^{31}$ As well, the Pachomian monks in Egypt ate a kind of a fish soup made of crushed small fish, which at the same time was considered by the Palestinians monks as nourishment for the sick. ${ }^{32}$

Subsequently, monks applied their own habits and ideas so long as it led them to unite with Christ. These ideas and beliefs were essentially shaped according to the social and economic constraints that surrounded them like those of the worldly people, but they were also enhanced by additional religious motives stemming mainly from their religious faith, experiences, and motives, whether they were living in solitude or communally. ${ }^{33}$

The monastic abstention from eating meat at Thebes is probably related to the monks' adaptation to the popular sayings of the Egyptian desert fathers, who believed that the intake of food was directly related to creating human desire, and many of them even regarded eating meat to be a result of the fall of Adam and Eve, and wanted to return to the prelapsarian state by observing a diet without meat and sex. ${ }^{34}$ Those monks who sometimes consumed fish, specifically those of the Monastery of Epiphanius and the monk Frange, could have been influenced both by the native sayings of the Egyptian desert fathers and by the social culture of late-antique and Byzantine food, which mixed recommendations long provided by Greek medicine with ascetic values and specific restrictions linked to the religious calendar: even the aristocracy changed their food habits and replaced meat with fish or shellfish during Lent and other fasting periods. ${ }^{35}$ Fish was also considered an essential food item that facili-

$30 \quad$ Wipszycka, "Resources and Economic Activities," p. 162.

$31 \quad$ Richter, "Daily life, Documentary Evidence," p. 138.

32 Heiska, The Economy and Livelihoods of the Early Christian Monasteries in Palestine, p. 37.

33 Richter, "Daily Life, Documentary Evidence," pp. 137-138.

34 B. Ward, The Sayings of the Desert Fathers: The Alphabetical Collection, Michigan, 1984; S. Kerner, C. Chou, and M. Warmind, Commensality from Everyday Food to Feast, London, 2015 .

35 B. Caseau, "Resistance and Agency in the Everyday Life of Late Antique Children (Third-Eighth century CE)," in: Children and Everyday Life in the Roman and Late Antique World, ed. L. Christian and V. Vuolanto, New York, 2017, pp. 226-227. 
tated union with Christ; and enjoyed a symbolic importance among the early Christians. The earliest literary reference to the symbolic fish is made by Clement of Alexandria, who recommended that his readers have their seals engraved with a dove or a fish. The symbol itself may have been suggested by the miraculous multiplication of the loaves and fishes or the repast of the seven disciples, after the resurrection, on the shore of the Sea of Galilee (John 21:9). Finally, the popularity of fish among the Christians was due principally to the famous acrostic consisting of the initial letters of five Greek words forming the word for fish (ichthys) which briefly but clearly described the character of Christ: Iesous Christos Theou Yios Soter, i.e. Jesus Christ, Son of God, Saviour. ${ }^{36}$ Thus there must have been a relationship between food and beliefs in monastic life, at least in Thebes, where all the monks believed that abstention from eating meat was essential for unifying themselves with Christ, while those who consumed fish added the social and religious culture to their beliefs about Christ.

It is also worth noting that other monastic communities outside Thebes, such as the monks of Bawit, kom-el-Nana, and Wadi Sarga or at some regions of Palestine, held additional monastic beliefs and motives that probably allowed them to consume fish and meat as well as other body-warming foodstuffs.

\section{Conclusion}

This article aimed to investigate the consumption of fish and meat in the monastic diets of Thebes from the sixth to the eighth centuries AD. The study also tried to detect the presence of fish and meat in other monastic sites, especially in Middle Egypt and beyond in Palestine, in order to set a broader focus for the case at Thebes.

The present study re-examined the various monastic diets at Thebes, adding the new archaeological and textual finds that have recently appeared there and consequently could help in the research. Thence there appeared that Theban monks depended primarily on wheat, bread, lentils and oil, and completely abstained from eating meat as it was not found at all, despite some traces of unspecified dung found in TT 85, and a mention of fodder in a Coptic ostracon

36 T. Rasimus, "Revisiting the Ichthys: A Suggestion Concerning the Origins of Christological Fish Symbolism," in: Mystery and Secrecy in the Nag Hammadi Collection and Other Ancient Literature: Ideas and Practices, ed. C.H. Bull, L. Ingeborg, and J. D. Turner, Leiden, 2012, pp. 327-348. 
from TT29. The latter probably refers to some beasts of burden frequently used by monks for transport, as meat is completely absent in the whole bulk of Coptic texts from Thebes discovered so far. However, some instances of fish consumption were found at TT29 and in the Monastery of Epiphanius, which in turn could lead us to suppose that some of the Theban monks consumed fish but abstained from eating meat.

The consumption of fish and meat was also found in some regions outside Thebes, specifically in the coenobitic monastery of Apa Apollo at Bawit, the monastic site of Kom el-Nana and the coenobitic monastery of Apa Thomas at Wadi Sarga, as well as abroad in some monastic regions at Palestine which display even more quantities than in Middle Egypt.

Therefore, monastic communities were not all similar in their dietary habits and applied their own thoughts and habits so long as it led them to unite with Christ. In addition monastic diets were not confined to a specific system of monasticism as most of the examples cited above belonged to different types of monasticism.

Thus we may suppose that the Theban monks who abstained from eating meat they could have adopted the widespread sayings of the Egyptian desert fathers not only in Egypt but also in the whole early Christian world, who saw that the intake of food was directly related to creating human desire, and even many of them thought that eating meat was a result of the fall of Adam and Eve. Those who abstained from eating meat but sometimes consumed fish could have been influenced in their abstention from eating meat by the native sayings of the Egyptian desert fathers, and in consuming fish by the social culture of late antique and Byzantine food that recommended eating fish instead of meat. Also we have to take into account the symbolic meaning of the fish and its implications as well its relationship with Christ.

Hence, there must have been a relationship between food, beliefs and habits in monastic life, at least of Thebes, where all the Theban monks believed that the abstention from eating meat was ideal for unity with Christ, while some of them consumed fish because they believed in its spiritual symbolism.

Outside Thebes, the monks of Bawit, kom-el-Nana, and Wadi Sarga do indeed resemble some of the Theban monks in their consumption of fish, particularly those of the monastery of Epiphanius and the monk Frange of тT29, but they were more closely related to some of the monastic communities at Palestine. This supposes that these communities in Egypt and Palestine held additional beliefs and motives that probably allowed them to consume fish and meat, where one could propose tentatively that they were applying the old practice that stemmed from Saint Peter's vision in Acts of the Apostles 10, as well the New Testament hints about not consuming food knowingly offered to 
pagan idols ( 1 Corinthians 8 ), a practice that was advocated by the early Church fathers.

Finally, the study of monastic diets and their spiritual implications could shed light on the religious ideas and habits of the monks and their beliefs, which were not confined to countries or borders but exhibit mutual thoughts and ideas, as well as suggesting tentatively that food practices were not related to a specific type of monasticism i.e. hermetic or coenobitic. Consequently one hope that more studies will be conducted on the role of monastic diets and their symbolic meanings, as well as investigating the consumption of fish and meat and many of the body-warmings foods in Egypt and Palestine.

\section{Acknowledgement}

I would like to express my deep gratitude for Professor Pauline Allen for her kind review and useful discussions. 